\title{
New Approaches to the Accountability of International Organizations
}

\author{
Kristen E Boon \\ Seton Hall University \\ kristen.boon@shu.edu \\ Frédéric Mégret \\ McGill University \\ frederic.megret@mcgill.ca
}

The United Nation's ('UN') record on accountability-related issues has never been perfect. Yet the UN has weathered prior storms and allegations of malfeasance, often without significant damage. ${ }^{1}$ This may be due to a generally deferential approach towards international organizations ('IOs') by lawyers. ${ }^{2}$ However, the 2013 launch of a class action asserting that UN peacekeepers had introduced cholera into Haiti was a watershed moment. ${ }^{3}$ The suit alleged that sewage from a base for Nepalese peacekeepers, who were part of an ongoing UN mission in Haiti, introduced a rare strain of cholera into one of the main

1 An exception may be the Oil for Food scandal. See Christopher M Blanchard and Kenneth Katzman, 'Iraq: Oil-for-Food, Illicit Trade and Investigation' (Research Paper No RL30472, Congressional Research Service Report, 11oth US Congress, 2007) 13 wherein 'Oil for Food' Scandal implicated senior UN officials in kickbacks, evidence of corruption and mismanagement on the part of UN officials. However, it is notable that incidents of corruption are far more frequent than sexual exploitation and abuse, although they rarely make the news, and when they do, they seem to pass over quickly. See eg Criminal accountability of United Nations officials and experts on mission, UN Doc A/71/167 (20 July 2016) annex II. Marc Santora, Somini Sengupta, and Benjamin Weiser, 'Former UN President and Chinese Billionaire Are Accused in Graft Scheme', New York Times (online), 6 October 2015 < https://www.nytimes .com/2015/10/07/nyregion/john-ashe-top-united-nations-official-is-accused-in-briberyscheme.html> named former president of the UN General Assembly John W Ashe in a criminal complaint alleging a broad pattern of corruption.

2 Eyal Benvenisti, 'Upholding Democracy Amid the Challenges of New Technology? What Role for the Law of Global Governance' (2018) 29 European Journal of International Law.

Georges $v$ United Nations (Southern District of New York, Complaint No 13-07146, 2013). 
tributaries. ${ }^{4}$ Cholera eventually killed over 10,000 people, and a number of scientific reports later confirmed the link to the UN. ${ }^{5}$ After the UN tersely responded to a claim from victims as 'not receivable, ${ }^{6}$ momentum built around the idea that the UN's response was akin to a denial of justice. ${ }^{7}$

As the UN searched to find a solution to the cholera outbreak that it, and perhaps more importantly Member States, could live with, the organization was assailed from another direction: the revelation of widespread sexual abuse by peacekeepers in the Central African Republic, coming on top of at least a decade of similar accusations. ${ }^{8}$ Reports that French peacekeepers had traded food for sexual favours rocked the organization again, showing a profound power imbalance between peacekeepers and the populations they are meant

4 As NPR reported-“Witnesses reported seeing overflowing toilets at the base spilling waste into a local stream", and even after the problem was identified it took a considerable period of time for the UN to fix the issue. See Jason Beaubien, 'Debate Continues Over UN Role in Bringing Cholera to Haiti', NPR (online), 18 August $2016<$ https://www.npr.org/ sections/goatsandsoda/2016/08/18/49049286o/debate-continues-over-u-n-role-in-bringingcholera-to-haiti>.

5 See, eg, Daniele Lantagne, et al, 'The Cholera Outbreak in Haiti: Where and how did it begin?' in G Nair and Y Takeda (eds), Current Topics in Microbiology and Immunology (Springer, 2013) 1; Renaud Piarroux, Rapport de mission sur l'épidémie de choléra en Haïti (UCLA Fielding School of Public Health, 2010) <http://www.ph.ucla.edu/epi/snow/piarrouxcholerareport_french.pdf >; Renaud Piarroux and Stanislas Rebaudet, 'Cholera in Haiti: Epidemic and Fight History, Prospect and Recommendations' (Report, Assistance Publique Hôpitaux de Marseille, July 2016) <http://www.ijdh.org/wp-content/uploads/2016/o8/Cholera-in-HaitiReport-July-2016-Final.pdf >. See also Dr Alejando Cravioto et al, 'Final Report of the Independent Experts on the Cholera Outbreak in Haiti' (Final Report, Secretary-General of the United Nations, 6 May 2011) <http://www.un.org/News/dh/infocus/haiti/UN-cholera-reportfinal.pdf >; Transnational Development Clinic et al, Peacekeeping without accountability: The United Nations' Responsibility for the Haitian Cholera Epidemic (Report, Yale Law School and the Yale School of Public Health, 2013).

6 Letter from Patricia O'Brien to Brian Concannon, 5 July $2013<$ http://www.ijdh.org/wp-content/uploads/2013/07/20130705164515.pdf $>$, citing the Convention on the Privileges and Immunities of the United Nations, opened for signature 13 February 1946, 1 UNTS 15 (entered into force 17 September 1946) arts I-VI.

7 See, eg, Pierre Schmitt, Access to Justice and International Organizations: The Case of Individual Victims of Human Rights Violations (Edward Elgar, 2017).

8 The solution was an apology, but not an admission of liability. A number of prominent Member States were opposed to the UN admitting liability, or to making compensation a budget item, such that all Member States would be assessed a contribution. Somini Sengupta, 'UN Apologizes for 2010 Cholera Outbreak', New York Times (online), , December 2016 <https:// www.nytimes.com/2016/12/o1/world/americas/united-nations-apology-haiti-cholera.html>. 
to protect. ${ }^{9}$ Despite longstanding organizational efforts to implement a ZeroTolerance Policy on Sexual Exploitation and Abuse, the continual surfacing of reports suggests little progress on issues of policy, and even some evidence of retaliation against whistleblowers. ${ }^{10}$

These various allegations against the UN and its peacekeepers have, it is true, opened a new chapter in the conversation about accountability. ${ }^{11}$ In 2017, Seton Hall Law School convened a group of scholars and lawyers to discuss UN accountability, and the conversation and speakers who participated, form the basis of this volume. ${ }^{12}$ Many have observed that had a corporation committed such acts in Haiti, it would have been required to pay significant amounts in compensation. ${ }^{13}$ Nor, in fact, is the problem consigned to such operations. They merely raise in more dramatic ways the ongoing question of IO accountability. For example, that debate recently expanded after two prominent tort actions were filed against International Financial Corporation ('IFC'), a

Karen McVeigh, 'Unicef admits failings with child victims of alleged sex abuse by peacekeepers', The Guardian (online), 13 February 2018 <https://www.theguardian.com/ global-development $/ 2018 / \mathrm{feb} / 13 /$ unicef-admits-failings-with-child-victims-of -alleged-sex-abuse-by-peacekeepers $>$; Nicolas Haque, 'UN chief in CAR: Peacekeepers accused of sexual abuse', Aljazeera (online), 25 October $2017<$ https://www.aljazeera .com/news/2017/10/rights-groups-failing-prosecute-peacekeepers-accused-rape -car-171024174502894.html>; Benoit Morenne, 'No Charges in Sexual Abuse Case Involving French Peacekeepers', New York Times (online), 6 June 2017 <https://www.nytimes .com/2017/01/06/world/africa/french-peacekeepers-un-sexual-abuse-case-central -african-republic.html>.

10 Sam Mednick, 'Despite the UN's 'zero tolerance policy', sexual exploitation continues in South Sudan', Devex (online), 12 March 2018, <https://www.devex.com/news/despitethe-un-s-zero-tolerance-policy-sexual-exploitation-continues-in-south-sudan-92270>; Somini Sengupta, 'U.N. Plans Reforms to Stamp Out Sexual Abuse by Peacekeepers', New York Times (online), 8 March 2017 <https://www.nytimes.com/2017/03/o8/world/americas/united-nations-antonio-guterres-peackeepers.html>. United Nations, Conduct of UN Field Missions: Sexual Exploitation and Abuse Investigations (2018) <https://conduct.unmissions.org/sea-investigations>; António Guterres, 'Secretary-General Stresses Need for Joint Action to Combat Corruption, Terrorism, Other Ills, at Commission on Crime Prevention and Criminal Justice' (Press Statement, SG/SM/19033-SOC/CP/371, 14 May 2018) <https://www.un.org/press/en/2018/sgsmigo33.doc.htm>.

11 Kristen E Boon, 'The United Nations as Good Samaritan: Immunity and Responsibility' (2016) 16 Chicago Journal International Law 341.

12 The conference proceedings can be viewed here: https://www.youtube.com/watch? $\mathrm{v}=$ pDNxTBKMobw .

13 See, eg, Ian Hurd, 'End the UN's Legal Immunity', The Hill (Washington, DC) 22 July 2016. Compare, for example, cases against Monsanto or BP Oil, in the wake of claims of mass torts. 
subsidiary of the World Bank. One of these cases, Jam $v$ IFC, was recently decided by the US Supreme Court. In a landmark holding, the Court found that IOs are no longer presumed to be absolutely immune under the International Organizations Immunity Act (IOIA).${ }^{14}$ And, in the press and court of public opinion at least, it has been clear that the UN has failed vulnerable persons in peace operations. Nonetheless, in a 2019 statement about led poisoning of Roma populations in Kosovo, the UN Secretary General adopted almost identical language to that used by the former UN Secretary General in responding to cholera in Haiti: apologizing for the UN's response while not admitting legal liability, and promising to set up a trust fund. ${ }^{15}$

Despite this high level of interest within and outside IOs about immunity, accountability, and remedies, the conversations have tended to become repetitive. Current reform efforts have left the issue of UN accountability at the margin. The International Law Commission's ('ILC') work on the responsibility of IOs only marginally addresses the question of IO accountability for third party claims. ${ }^{16}$ The UN seems to have withstood challenges to its immunity, a major stumbling block in any attempt to make it accountable. The debate on UN accountability for the cholera epidemic, the question of sexual abuse by peacekeepers, or lawsuits against international financial institutions have tended to be siloed at the expense of a deeper understanding of how all, at various levels, implicate common underlying questions about accountability. More radical calls to transcend the existing limitations of the system by, for example, doing away with peacekeepers' immunity, have perhaps unsurprisingly elicited little traction. As new incidents of malfeasance have come to light, frustration has predictably and rightly mounted.

14 This case is analysed further in the contribution by Treichl and Reinisch in this issue.

15 UN is Rebuked by its own expert for neglecting Kosovo Poisoning Experts, NYT, March 13 (2019) <https://www.nytimes.com/2019/03/13/world/europe/roma-un-lead-poisoning .html>. Jose Alvarez, 'The United Nations in the Time of Cholera' (2014) American Journal of International Law Unbound 22, 23.

16 Although the ILC has, for some time, had immunities of IOs on its long-term program of work it has not proceeded. However, a narrower but related topic, involving disputes against IOs, that was proposed in 2016 may now advance the issue. Nonetheless, this topic would address "disputes between IOs and states (both member and non-member states), and disputes between IOs". As currently conceived, it would not involve third-party disputes against the Organization such as employment or contract disputes at this time, nor would it address the question of organizational immunities. See 'The settlement of international disputes to which international organizations are parties' in 'Annual report of the International Law Commission on the work of its sixty-eighth session' (2 May-10 June and 4July-12 August 2016) [2016] II (2) Yearbook of the International Law Commission 387. 
This suggests the need to think anew about the issue in ways that transcend some of the repetitiveness of the debate. The goal of this issue of the $I O L R$ is therefore to offer new and creative ways to think about the issue of accountability of international organizations. It proposes to treat both the sort of systemic organizational failure evidenced in the mass torts cases and more localised but equally systemic problems of sexual abuse, as symptomatic of broader and deeper dilemmas. It suggests the need to think creatively about what international law does, can and should do in order to give a meaningful voice to victims of violations of their rights at the hands of IOs. Although focused on lessons learned from the past, it will also keep a keen open eye on the possibilities of the future.

One threshold issue in discussing the accountability of international actors like the UN or the International Financial Institutions ('IFI'), involves the definition of accountability itself, a question that clearly runs through all articles in this issue. Accountability is not the same thing as a narrow international legal notion of IO responsibility ${ }^{17}$ and designates a wide range of processes by which international organizations may be led to account for their actions. In a seminal article, Grant and Keohane defined accountability as implying "that some actors have the right to hold other actors to a set of standards, to judge whether they have fulfilled their responsibilities in light of these standards, and to impose sanctions if they determine that these responsibilities have not been met". ${ }^{18}$ This political notion of accountability has been roughly implemented in the international legal order through judicial and administrative mechanisms, and within the legal orders of IOs. ${ }^{19}$ However, in the case of IOs there continues to be push back on a basic question: what are the standards of accountability applicable to the UN or the IFIs? Despite the fact that organizations are more accountable in many ways than powerful states given the financial control and voting rights exercised by states in relation to IOs, they are also perceived as unchecked. ${ }^{20}$

17 For an assessment of the Articles on the Responsibility of IOs, see Maurizio Ragazzi (ed), Responsibility of International Organizations: Essays in Memory of Sir Ian Brownlie (2015).

18 Ruth Grant and Robert Keohane, 'Accountability and Abuses of Power in World Politics' (2005) 99 American Political Science Review 29.

19 Christiane Albhorne, 'Remedies against International Organizations - A Relational Account of International Responsibility' in Dan Sarooshi (ed), Remedies and Responsibility for the Actions of IOs (Brill Nijhoff, 2014) vol 14, 525.

20 Ibid. "The prevailing view in the international relations literature of multilateral organizations, such as the World Bank and World Trade Organization, is that these entities are weak relative to states. But critics of globalization view such organizations as relatively uncontrolled, criticising them as 'unaccountable' while celebrating the democratic accountability of states". 
One reason for the disconnect is that it is apparent that many organizations, like the UN, have adhered to a much narrower definition of accountability, with a clear tendency to use the label in external rather than internal situations. For example the UN Legal Counsel referred to the creation of international criminal tribunals in conflict zones as evidence of the UN's 'culture of accountability'. ${ }^{21}$ Even when internal policies such as the UN's Human Rights Due Diligence Policy have been implemented, the focus has tended to be on procedures and monitoring, rather than on remedies. ${ }^{22}$ And while some more robust mechanisms exist such as the Integrated Office of the United Nations Ombudsman and Mediation Services ('UNOMS') or the UN Dispute Tribunal, ${ }^{23}$ their mandate is exclusively oriented towards internal complaints, despite old calls for the ombudsman position to have an external dimension as well. ${ }^{24}$ As such, organizations have typically engaged in what the International Law Association ('ILA') has identified as 'first level' accountability, including monitoring and procedures, rather than 'second' or 'third' level work, such as establishing remedies for torts or breaches of international law and human rights. ${ }^{25}$ Two notable exceptions are the occasional peace operation and international administration ombudspersons ${ }^{26}$ and the Al Qaida/ISIL Ombudsperson. ${ }^{27}$ Both have 'external' dimensions, but remain highly specialised, ad hoc and context specific.

21 For example, in a speech to the ILC, the UN Legal Advisor, Miguel de Serpa Soares, discussed the new "culture of accountability" however the examples given were almost exclusively in the criminal domain. See Miguel de Sorpa Soares, 'Statement' (Speech delivered at the first part of the seventieth session of ILC, New York, 9 May, 2018).

22 See UN Due Diligence Policy, UN Doc A/67/775 (5 March 2013). However, the UN Dispute Tribunal, which hears employment cases, can order remedies. See UN Disputes Tribunal <http://www.un.org/en/oaj/dispute/>.

23 About the UN Dispute Tribunal <http://www.un.org/en/internaljustice/undt/about-contact.shtml>.

24 Florian Hoffmann and Frédéric Mégret, 'Fostering Human Rights Accountability: An Ombudsperson for the United Nations?' (2005) 11 Global Governance: A Review of Multilateralism and International Organizations 43.

25 However, see discussion of the UN's system established via General Assembly Resolution 247: 'Accountability of International Organizations' (Final Report, International Law Association, 2004).

26 Marcus G Brand, 'Institution-Building and Human Rights Protection in Kosovo in the Light of UNMIK Legislation' (2001) 70 Nordic Journal of International Law 461.

27 Clemens A Feinäugle, 'The UN Security Council Al-Qaida and Taliban Sanctions Committee: Emerging Principles of International Institutional Law for the Protection of Individuals?' The Exercise of Public Authority by International Institutions (Springer 2010). 
Another reason conversations around accountability are fraught is that the best interests of states are not necessarily co-terminal with the best interests of IOs. As Grant and Keohane note, "states can exercise significant financial and supervisory accountability over organizations, given their budgetary control and voting rights". ${ }^{28}$ But states often have ambivalent attitudes towards IO accountability and may wish to avoid the IO or indeed indirectly shield themselves from being responsible for reparations. They may further seek to use the corporate form of the IO, to obscure their own role as voters in multilateral fora or implementers of UN mandates. They may further seek to hide behind the specific privileges and immunities provided by the organization. ${ }^{29}$

Having said that, accountability demands have become increasingly hard to shut out. The main reason is the striking emergence of third-party claims. As IOs' mandates have expanded, it is not surprising that third parties, including individuals and other non-state entities, have on occasion stood to be harmed by them. The intensity of their demands has been magnified by human rights discourse and innovations in international criminal law which emphasise the importance of a victim centered approach to proceedings and remedies, occasionally piercing the corporate veil and emphasizing the right to remedies. ${ }^{30}$ These claims have also had the significant support of local and transnational civil society actors keen to relay the messages of the victims and give them dignity. In this context, one body of law that could have filled some of the gaps, the Articles on Responsibility of International Organizations, has potential but remains very focused on the responsibility of IOs towards states. Despite the fact that IO as exercise public authority and have an unmistakable potential to affect human rights, individuals have been 'left in the cold' by this latest attempt to develop international law on the topic.

The contributions in this volume thus offer new perspectives on the content and scope of UN accountability from a variety of political science and legal perspectives. How might one advance the conversation when it comes to IO accountability? What leads have been missed or could be better explored? Is international law part of the problem or part of the solution, and if so how? Although several articles are rooted in the emblematic Haiti crisis or the problem

$28 \quad$ Ibid 37 .

29 This motivation has also been recognised with regards to state complicity or aiding and assisting IOs. See ARIO art 14-17.

30 See generally Schmitt, above $\mathrm{n}$ 7. See also The UN Basic Principles and Guidelines on the Right to a Remedy and Reparation for Victims of Gross Violations of International Human Rights Law and Serious Violations of International Humanitarian Law, UN Doc A/RES/6o/147 (21 March 2006). 
of sexual violence by peacekeepers, they leave little doubt that the problem is both deeper and broader, and that the time has come for more cross-cutting comparison and experience sharing, as well as a dose of thinking outside the box.

Kristina Daugirdas opens the symposium with a reflection on how reputation sustains accountability practices beyond the law: to what extent is and should the UN be motivated by the fear of reputational harm? How do IOs' structures some make it harder to determine the exact chain of responsibility in cases of abuses and therefore deflect demands for accountability? Should we defer seriously to those reputational mechanisms if the law is found wanting? Hoping that reputation alone will help deal with persistent accountability deficits may be to expect too much of the costs imposed on some IOs by potential reputational loss. In fact, the legal position on accountability may be negatively influenced by reputational concerns that bear little relation to the law. Daugirdas argues that persistent uncertainty about the facts, for example, may hamper demands for accountability and allow organizations to deflect critique. The same is true of uncertainty about the law, although the UN may have overplayed that card in the context of the cholera epidemic, to the point of weakening its reputation for compliance. Moreover, IOs may have different reputational constituencies: the UN for example may be less concerned about how it is perceived in the streets of Port au Prince than its image with donor states in the General Assembly.

On a more doctrinal plane, Carla Fertsman then investigates how the UN systemically escapes accountability in relation to third party claims, particularly mass torts, by arguing that the settlement of such claims should be left to the lex specialis of the UN. She challenges whether this is a correct designation, and she argues that the tendency of the UN to 'opt out' of the general regime of IO responsibility when it comes to harm suffered by third parties is not only one of the causes of its unaccountability but is conceptually unsound given the extent to which the UN's internal policies may affect third parties. But what is one to do if such is UN practice? Might there be ways to more efficaciously make the UN accountable even under its own lex specialis?

Frédéric Mégret suggests that the problem may be not so much with the UN itself but, in fact, an exclusive focus on the UN. In particular, he argues that insufficient attention has been devoted to the role of the host state in ensuring accountability and justice. The literature on international organization accountability is, perhaps understandably, heavily focused on international organizations themselves. This had led victims of various abuses by the UN to seek remedies directly against it before domestic courts, often raising insurmountable problems of immunity and with little success. What seems missing from the search for accountability is the notion that the host state could 
exercise assert some kind of diplomatic protection on behalf of its nationals and against the international organization. If nothing else, for example, Haiti could have called for the setting up of a claims commission, the principle of which is generally anticipated in Status of force agreements. That Haiti may have had good political reasons not to press the case for accountability too much with the UN, on which it remains very dependent for the provision of basic services and assistance, should not obscure that in the process it may have added insult to the injury of Haitian victims. Strikingly, civil society actors in Haiti have sought to bind the Haitian government 'from within' by launching several civil society initiatives and legal suits to require it to invoke diplomatic protection.

Also echoing the significance of host state responsibility, the symposium broadens the scope of accountability, through Clemens Treichl and August Reinisch's examination of the potential role of national statutes in current cases against the IFC in US courts. In particular, they examine the issue of jurisdictional immunity in the context of international project finance, and focus on accountability through the interplay between international and domestic US norms. A key finding is that US courts tend to grant more extensive immunities than international law requires. While doubts persist as to whether domestic courts are a suitable venue for claims brought by project-affected people, this contribution demonstrates great interest in accountability issues regarding international financial institutions in domestic courts.

The volume concludes with a contribution by Kristen Boon who discusses accountability from the perspective of remedies. She assesses the interplay between immunities and compensation schemes in UN practices, and then compares this to the practices of the US and other countries with militaries who operate abroad. She notes that UN member states have more developed practices than the UN itself where it comes to compensation and remedies. Moreover, she notes that the UN has much to learn from its TCCs with regards to best practices. She proposes that the UN more regularly ex gratia payments where individuals are harmed during peacekeeping missions. She notes that were the UN to adopt a more transparent process and make, for example, small and regular payments according to a set schedule, the accountability gap would start to close and the UN would have a better chance of winning the hearts and minds of the populations its seeks to protect. This would be a step towards providing compensation in cases of recognized legal responsibility, while respecting some practical constraints on the organization.

These reflections suggest that there is no easy fix to the UN's accountability problem, despite wide agreement that more should be done. The Haiti cholera outbreak illustrates some of the challenges that remain: an international law 
that still seems quite devoted to the notion of immunity; reputational harm that is too diffuse and fragmented to precipitate a change of policy; the confusion surrounding some core parts of the responsibility of the international organization and the ease with which the UN can still elude fundamental issues of responsibility; the inertia of host states, despite emerging efforts to make them part of the solution; and the challenges of seeking remedies before domestic courts. Nonetheless the symposium does suggest that creative thinking has a role in devising strategies that combine law and politics, and connect different domestic and international constituencies. As flagged in the introduction, this issue suggests the need for a deeper analysis of how different types of claims currently considered to involve 'accountability' may mean quite different things in the various contexts of individual tort claims, instances of corruption, sexual misconduct, employment disputes, and relatedly what dispute resolution mechanisms or remedies are appropriate in each case. Other issues await examination, such as the possibility of thinking in terms of shared accountability in international law, or alternatively, about different ways of thinking about how victims' voices should be heard. The full and multifaceted accountability of international organizations seems as necessary as it remains elusive. 